\title{
Study on the Comprehensive Evaluation of the
}

\section{Financial Core Competitiveness for the Listed}

\section{Companies in Chinese Steel Industry}

\author{
Yanhui Wang, Yajun Guo \& Yanqing Zhuang \\ School of Business Administration \\ Northeastern University \\ Shenyang 110004, China
}

Tel: 86-24-8368-7530Ｅ-mail: yhwang@mail.neu.edu.cn

The research is financed by the project of Liaoning Provincial Social Science Fund (No. L05CJY045). (Sponsoring information)

\begin{abstract}
The financial management activity is the important part of the enterprise economic activity, and the enterprise core competitiveness is decided by the financial core competitiveness to certain extent, so the scientific measurement of the financial core competitiveness of the enterprise is very important to know the financial management performance of the enterprise and effective form the core competitiveness of the enterprise. In this article, we established a set of the index system which could comprehensively evaluate the financial core competitiveness of the listed company, took 15 listed steel companies in Shenzhen Stock Exchange as the examples to analyze and evaluate the financial core competitiveness of the listed companies, and finally made advices to cultivate and strengthen the financial core competitiveness of the listed company.
\end{abstract}

Keywords: Financial core competitiveness, Comprehensive evaluation, Listed companies, Steel industry

In China, some scholars had put forward relative financial theories about the accounting core competitiveness, the enterprise financial core ability and the core competitiveness. Wang Yuetang (Wang, 2004, P. 65-68) et al put forward the concept of the accounting core competitiveness, and pointed out the accounting measurement and the report composed the accounting core competitiveness just for the accounting science system. Feng Qiaogen (Feng, 2003, P. 26-27) put forward the core competitiveness-oriented new finance science view, i.e. the core competitiveness finance, and pointed out the core competitiveness finance was a sort of systematical financial control and management method which took the capital investment, the income activity and the relative financial relations of the value chain or the supply chain enterprise group as the research objects, took the market competition as the drive, acquired the enterprise competitive advantage and tried to create values for consumers under the guidance of the economics and the management theory. Zhu Kaixi (Zhu, 2001, P.10) definitely put forward the concept of the enterprise financial core ability. And he pointed out that as the enterprise financial management target, the enterprise financial core ability is the essential target of the enterprise financial management activity, and it is the start and the end-result of the enterprise financial management activity. The financial core ability of one enterprise may be not completely same with the financial core abilities of other enterprise, but they are not copied each other.

Based on different scholars' essential cognitions about the core competitiveness from the integrated view, the knowledge view, the cultural view and the organization view, Huang Jigang (Huang, 2003) put forward that the core competitiveness of the enterprise was formed through the management integration, and it could more significantly realize the dynamic ability that the value demand was hardly simulated by the competitive opponents, and the core competitiveness was generally presented by the technical ability and the management ability or both organic combination of the enterprise. The management ability of the enterprise includes the R\&D management ability, the production \& manufacturing management ability, the marketing management ability, the financial management ability and the planned organization management ability. Any ability or any multiple abilities in these abilities which are leading for the competitive opponents will compose the core competitiveness of the enterprise which will make the enterprise obtain the advantages of the sustainable competition and the development. Based on the cognition of the core 
competitiveness, we think the financial core competitiveness is a series of special, excellent and dynamically developmental enterprise finance competitive ability which takes the knowledge and innovation as the basic core and roots in the financial management system engineering of the enterprise. It is the updating and optimization of the enterprise financial management ability, and it is the core competitiveness of the enterprise.

The establishment of the financial core competitiveness is based on the resources of the enterprise, but the resource doesn't equal to the ability. The management scholar of the ability theory, Christensen pointed out that "the resource itself almost has not the ability of the production, and the ability is generated by the production activity which requires combining and harmonizing the resources". According to Canada doctor Mansour Javidan's view of the core competitive relation, we think the formulation process of the financial core competitiveness is the process which reasonably and effectively organizes and harmonize financial resources and continually innovate in the financial competitive ability according with the practice of the enterprise. In this process, we can treat all problems in the financial core competitiveness domain as the system composed by the interactive functions of various factors, and this system includes four sorts of factor such as the ability resource, the base ability, the ability system and the mechanism and ability status. And the studying ability, the financial relation ability, the financial control ability, the information processing ability and the financial alarm ability are implicit factors to form the base ability of the financial core competitiveness. The base ability acts with relative ability systems and mechanism each other, which is very important to form the financial core competitiveness of the enterprise. The ability status is the dominant factor of the financial core competitiveness, and it includes not only the material entities such as the financial human resource and the asset appropriation which are used to develop the financial management activity, but also the result integrating and innovating in the basic ability of the financial management, i.e. the representation carrier of the financial core competitiveness.

However, when the enterprise tries to exert the idea of the core competitiveness from the view of the financial core ability, the largest difficulties include many problems such as whether does the enterprise have the financial core competitiveness, where is the financial core competitiveness, and how strong is the financial core competitiveness. Through it is very difficult to establish objective evaluation standard of the financial core competitiveness with general meaning, but the enterprise can not avoid the standard when it wants to use it, and it should organically integrate the decomposing measurement and the overall grasp of the financial core competitiveness. Therefore, when we design the evaluation index system, we should start from the formation not from the result of the financial core competitiveness, which will essentially indicate the size and the formation reason of the financial ability of the evaluated enterprise. The concrete design indexes are seen in Table 1.

According to established evaluation index system, we adopt the linearly weighted comprehensive evaluation method to evaluate the financial core competitiveness. The corresponding evaluation index set is called as $\mathrm{X}=\{\mathrm{X} 1, \mathrm{X} 2 \ldots \mathrm{X} 10\}$, where, $\mathrm{X} 1$ is the super title financial personnel proportion, $\mathrm{X} 2$ is the information-based level of the financial management information system, $\mathrm{X} 3$ is the industrial ranking of the total assets, $\mathrm{X} 4$ is the industrial ranking of the financing size in recent three years, $\mathrm{X} 5$ is the company governance index, $\mathrm{X} 6$ is the interior control status, $\mathrm{X} 7$ is the value of $\mathrm{Z}, \mathrm{X} 8$ is the investment growth rate, $\mathrm{X} 9$ is the industrial ranking of the cash flow amount, and $\mathrm{X} 10$ is the cash dividend payout rate.

We select Shi Donghui's new research results (Shi, 2004, P.41-48) of Shanghai Stock Exchange Research Center, i.e. the Chinese listed company governance index, to reflect the company governance level, Company governance index $=35 \% \times$ values of majority stockholder behavior $+25 \% \times$ values of key personnel's restriction and encouragement $+25 \% \times$ values of the structure and operation of the directorate $+15 \% \times$ values of information transparency, and the concrete composing is seen in Table 2.

The financial alarm ability of the enterprise is finally embodied in the result that the enterprise implements the financial alarm system according with the characters and the requirements, and we select unstable Edward Arman's Z model which can reflect the enterprise financial status. The model use five financial rates to generate the total discrimination value (value of $Z$ ) through the weighted integration. The discriminant function is $\mathrm{Z}=1.2 \mathrm{Y}_{1}+1.4 \mathrm{Y}_{2}+3.3 \mathrm{Y}_{3}+0.6 \mathrm{Y}_{4}+0.999 \mathrm{Y}_{5}$, where, $\mathrm{Y} 1$ is the rate of the operation capitals and the asset amount, $\mathrm{Y} 2$ is the rate of the retained earnings (unappropriated profit) and the asset amount, $\mathrm{Y} 3$ is the rate of the earnings before interest and tax and the asset amount, Y4 is the rate of the market value amount of the common stock and the preferred stock and the book debt value amount, Y5 is the rate of the sales amount and the asset amount. Generally, the value of $\mathrm{Z}$ is lower, the enterprise is more possible to be bankrupted, and the financial alarm system is not more perfect, the financial alarm ability of the enterprise is lower.

For the industrial ranking of the evaluation index total assets, the industrial ranking of the financing size of various channels in recent years, the investment growth rate, the industrial ranking of the cash flow amount, and the cash dividend payout rate can be directly obtained from the simple computation or the data in the enterprise bulletin and yearly report. For the super title financial personnel proportion, we should enter into the enterprise and obtain the data 
through the investigation, and for the information-based level of the enterprise financial management information system, we should retain the experts to research and evaluate it according to the situation whether it implements the manual accounting system or the computer accounting system, or the situation whether it is in the stage of MRP, in the stage of MRP2 or the stage of ERP.

Because of the existing certain limitation (only in small range), in this article, we select 8 indexes in the above design index system as the comprehensive evaluation index of the financial ability of the listed company, and they are the information-based level of the financial management information system, the industrial ranking of the total assets, the industrial ranking of the financing size, the company governance index, the value of $Z$, the investment growth rate, the industrial ranking of the cash flow amount, and the cash dividend payout rate.

When we establish the evaluation index of the financial core competitiveness, we adopt the classification design, and when we confirm the weights, we adopt the new evaluation index weight method, i.e. the method of G1 put forward by Professor Guo Yajun (Guo, 2002). The method needs not to establish the discriminant matrix and the consistency check, and the computation will be exponentially reduce comparing with the method of AHP, and the confirmed index weight possesses the character of the isotonicity.

For the comparison and the statistics, the evaluated 15 steel enterprises in the article are all listed in the Shenzhen Stock Exchange. The relative data about the listed companies selected in the article are all from the appointed information disclosure websites such as the Juchao Information (http://www.bj.cninfo.com.cn) and the Stock Star (http://www.stockstar.com). The data are from the yearly report of each company in 2003, and we also select relative data in 2001 and in 2002 for the necessary indexes, and the researches are all established on the base of the sufficient trust for the listed companies, and the premise that the relative data are real and reliable, and the researches don't include exceptional situations such as the accounting information distortion.

For the pretreatment of the original data, the total principle is that the qualitative indexes are uniformly translated into the quantitative indexes, and the quantitative indexes are uniformly translated into the non-dimensional and current maximum-sized indexes, and the total value of each index is 10 . The concrete operation includes following aspects.

(1) For the industrial ranking of the total assets, the evaluation index uses $N / 42$ to represent the place in the competition of certain company, and uses 1-N/42 to translate it into the maximum-sized index, and multiply with 10 , and the final value of the evaluation index will be obtained.

(2) For the industrial ranking of the cash flow amount and the industrial ranking of the financing amount in recent three years, the processing method is same with the ranking index of the total assets.

(3) For the evaluation method of the listed company governance index, first, compute the value of every problem, and the answers of 12 problems in the evaluation system include two sort of selection, i.e. yes or no which are respectively endowed "0" and "l". Second, compute the value of every item. For the majority stockholders' behaviors, the selection, encouragement and restriction of the key personnel, the structure and operation of the directorate, and the information disclosure transparency, we respectively compute the value sums, and divide the problem amount of the item, and multiply 10 , so we can obtain the final value of the item. Therefore, the value sum of every item is 10 points. Finally, according to the corresponding weights of various items, we can compute the total values of the company governance index.

(4) For two indexes such as the investment growth rate and the cash dividend payout rate, multiple the computed values with 10 , and we can obtain the final evaluations of various indexes.

(5) For the information-based level of the financial management information system, we correspondingly endow the values such as $8-10,6-8,4-6,2-4$ and 1-2 points according to the adopted information processing systems including ERP, MRP2 and MRP, and the general computer accounting system and the traditional manual accounting system.

(6) For the value of $Z$, if it exceeds 2.675, evaluate it by the point in 8.0-10.0, and it is in 1.81-2.675, evaluate it by the point in 4.0-8.0, and it is smaller than 1.81, evaluate it by the point in 1.0-4.0. For example, if the $Z$ value of certain company is 2.42 through the computation, the pretreatment process is $Z=[(2.42-1.81) /(2.675-1.81)] \times(8-4)+4$.

For the relative importance of the index in the index system, in this article, we designed corresponding investigation questionnaires, and surveyed part of theoretic scholars and financial personnel, and relative masters. In this investigation, we sent out 12 questionnaires and returned 10 effective questionnaires. According to above method, we computed and confirmed the weights of various indexes (seen in Table 3).

By above financial core competitiveness index system through the pretreatment and the weight coefficients confirmed by the method of G1, we could obtain the comprehensive ranking of the financial core competitiveness for 15 steel enterprises (seen in Table 4).

Through the comparison of the values of the financial core competitiveness comprehensive evaluation various indexes of 15 steel enterprises listed in Shenzhen Stock Exchange, we could find that when other 14 steel enterprises still used 
the general computer system, the Capital Iron and Steel Company (000959) first used advanced ERP system, which enhanced the information-based level of the financial management information system and made it change from the information reservoir to the information provider and information sharer. Only this index made the Capital Iron and Steel Company rank first in the comprehensive evaluation of the financial core competitiveness. At the same time, the financing ability of the Capital Iron and Steel Company also ranked first in 15 steel enterprises, but it didn't use large scale investment to quickly extend the scale, but it used the financed capitals in the production management by its excellent financial organizational harmony ability (rank second) and the capital utilization ability (rank first), and formed the financial core competitiveness better than other enterprise in the same industry.

Otherwise, the five enterprises which comprehensive evaluation value of the financial core competitiveness ranked in the front were higher than other later five enterprises for five evaluation indexes including the total asset, the financing scale in recent three years, the company governance index, the investment growth rate and the net cash flow.

Therefore, for Chinese listed steel enterprise, to keep higher financial competitive advantage in the drastic market competition, we should continually dig the potentials and keep the leading status in the base resource, the financing ability, the investment ability, the capital utilization ability and the financial organization and harmony ability. For the listed companies in other various industries, for the question how to establish and enhance their financial core abilities, we can analyze and research and put forward corresponding policy advices according to above method.

\section{References}

Feng, Qiaogen. (2003). The Core Competitiveness Finance: New Financial View. Shanghai Accounting, No.3, P. $26-27$.

Guo, Yajun. (2002). Theory and Method of the Comprehensive Evaluation. Beijing: Sciences Press.

Huang, Jigang. (2003). Dynamic Management of the Core Competitiveness. Beijing: Economic Management Press.

Shi, Donghui \& Situ, Da'nian. (2004). An Empirical Study on the Quality of Corporate Governance and Its Effect on the Performance of the China's Listed Companies. Nankai Business Review, No.1, P. 41-48.

Wang, Yaotang, Mao, Danxia \& Luohui. (2004). The Core Competency of Accounting: the Impact and Prospect of Information Technology. Accounting Research, No.1, P. 65-68.

Zhu, Kaixi. (2001). Financial Management Objective and Enterprise Financial Core Ability. Collected Essays on Finance and Economics, No. 5, P.10. 
Table 1. Evaluation indexes of the financial core competitiveness

\begin{tabular}{|c|c|c|c|c|}
\hline & $\begin{array}{l}\text { Basic } \\
\text { factors }\end{array}$ & $\begin{array}{l}\text { Evaluation } \\
\text { factors }\end{array}$ & Evaluation indexes & Meaning of index \\
\hline \multirow{10}{*}{$\begin{array}{l}\text { Financial } \\
\text { core } \\
\text { competiti } \\
\text { veness }\end{array}$} & \multirow{4}{*}{$\begin{array}{l}\text { Ability } \\
\text { resource }\end{array}$} & $\begin{array}{l}\text { Financial } \\
\text { human } \\
\text { resource }\end{array}$ & $\begin{array}{l}\text { Super title financial } \\
\text { personnel } \\
\text { proportion }\end{array}$ & $\begin{array}{l}\text { Super title financial personnel quantity/ Financial } \\
\text { total quantity }\end{array}$ \\
\hline & & $\begin{array}{c}\text { Information } \\
\text { processing } \\
\text { ability }\end{array}$ & $\begin{array}{l}\text { Information-based } \\
\text { level of the } \\
\text { financial } \\
\text { management } \\
\text { information system }\end{array}$ & $\begin{array}{l}\text { Adopted information processing system: popular } \\
\text { accounting computer application software, MRP, } \\
\text { MRP2 and ERP system }\end{array}$ \\
\hline & & Asset size & $\begin{array}{l}\text { Industrial ranking } \\
\text { of the total asset }\end{array}$ & \\
\hline & & $\begin{array}{l}\text { Financial } \\
\text { relation } \\
\text { ability }\end{array}$ & $\begin{array}{l}\text { Industrial ranking } \\
\text { of the financing } \\
\text { amount in recent } \\
\text { three years }\end{array}$ & \\
\hline & \multirow{3}{*}{$\begin{array}{l}\text { Ability } \\
\text { system } \\
\text { and } \\
\text { mechani } \\
\text { sm }\end{array}$} & $\begin{array}{c}\text { Financial } \\
\text { organization } \\
\text { and harmony } \\
\text { ability }\end{array}$ & $\begin{array}{l}\text { Company } \\
\text { governance index }\end{array}$ & $\begin{array}{c}\text { Company governance index }=35 \% \times \text { values of } \\
\text { majority stockholder behavior }+25 \% \times \text { values of } \\
\text { key personnel's restriction and encouragement } \\
+25 \% \times \text { values of the structure and operation of } \\
\text { the directorate }+15 \% \times \text { values of information } \\
\text { transparency }\end{array}$ \\
\hline & & $\begin{array}{l}\text { Financial } \\
\text { control } \\
\text { ability }\end{array}$ & $\begin{array}{l}\text { Interior control } \\
\text { status }\end{array}$ & Opinions of interior system report \\
\hline & & $\begin{array}{c}\text { Financial } \\
\text { alarm ability }\end{array}$ & Value of $\mathrm{Z}$ & $\begin{array}{c}\mathrm{Z}=1.2 \times \text { operation capital } / \text { total } \\
\text { assets }+1.4 \times \text { retained earnings } / \text { total assets } \\
+3.3 \times \text { profits before interest and tax } / \text { total assets } \\
+0.6 \times \text { the market value of shares } / \text { debt } \\
\text { amount }+0.999 \times \text { sales amount } / \text { total assets }\end{array}$ \\
\hline & \multirow{3}{*}{$\begin{array}{c}\text { Ability } \\
\text { status }\end{array}$} & $\begin{array}{l}\text { Investment } \\
\text { ability }\end{array}$ & $\begin{array}{l}\text { Investment growth } \\
\text { rate }\end{array}$ & $\begin{array}{c}\text { The growth rate of the sum of the building } \\
\text { engineering, fixed assets and long-term } \\
\text { investment }\end{array}$ \\
\hline & & $\begin{array}{l}\text { Capital } \\
\text { exertion } \\
\text { ability }\end{array}$ & $\begin{array}{l}\text { Industrial ranking } \\
\text { of the cash flow } \\
\text { amount }\end{array}$ & \\
\hline & & $\begin{array}{l}\text { Distribution } \\
\text { ability }\end{array}$ & $\begin{array}{l}\text { Cash dividend } \\
\text { payout ratio }\end{array}$ & $\begin{array}{l}\text { Cash dividend in recent three years/ Cash stock } \\
\text { dividend in recent three years }\end{array}$ \\
\hline
\end{tabular}


Table 2. Composing of the company governance index

\begin{tabular}{|c|c|}
\hline Governance layer & Subdivision index \\
\hline \multirow{3}{*}{$\begin{array}{l}\text { Majority stockholder } \\
\text { behavior }(35 \%)\end{array}$} & $\begin{array}{l}\text { Whether does the associated trade exist between the majority } \\
\text { stockholder and the listed company? }\end{array}$ \\
\hline & $\begin{array}{l}\text { Whether do the majority stockholders and their associated } \\
\text { parties occupy the capitals of the listed company? }\end{array}$ \\
\hline & $\begin{array}{l}\text { Whether does the listed company offer guarantees for the } \\
\text { majority stockholders and their associated parties? }\end{array}$ \\
\hline \multirow{4}{*}{$\begin{array}{l}\text { Key personnel's selection, } \\
\text { restriction and encouragement } \\
(25 \%)\end{array}$} & $\begin{array}{l}\text { Whether does the general manager generated by the majority } \\
\text { stockholders? }\end{array}$ \\
\hline & $\begin{array}{l}\text { Whether do the board chairmen or the general manager draw } \\
\text { the salaries in the listed company? }\end{array}$ \\
\hline & $\begin{array}{l}\text { Whether do the board chairmen or the general manager hold } \\
\text { the shares of the listed company? }\end{array}$ \\
\hline & $\begin{array}{l}\text { Whether does the listed company evaluate the cash dividend } \\
\text { in the yearly distribution? }\end{array}$ \\
\hline \multirow{3}{*}{$\begin{array}{l}\text { Structure and operation of } \\
\text { the directorate }(25 \%)\end{array}$} & $\begin{array}{l}\text { Whether does the independent director exist in the directorate } \\
\text { of the listed company? }\end{array}$ \\
\hline & $\begin{array}{l}\text { Whether do the board chairman and the general manager } \\
\text { occupied by same one? }\end{array}$ \\
\hline & $\begin{array}{l}\text { Whether does the board chairman or the general manager of } \\
\text { the listed company belong to the majority stockholders? }\end{array}$ \\
\hline \multirow{2}{*}{$\begin{array}{c}\text { Reserved information } \\
\text { disclosure transparency }(15 \%)\end{array}$} & $\begin{array}{l}\text { Whether do the enrolled accountants bring forth the abnormal } \\
\text { reserved opinions in the yearly accounting report? }\end{array}$ \\
\hline & $\begin{array}{l}\text { Whether is the evaluation year condemned publicly by the } \\
\text { Shanghai Stock Exchange and Shenzhen Stock Exchange because } \\
\text { of information disclosure? }\end{array}$ \\
\hline
\end{tabular}

Table 3. Evaluation index weights

\begin{tabular}{|c|c|c|c|}
\hline $\begin{array}{c}\text { Name of evaluation } \\
\text { factor }\end{array}$ & $\begin{array}{c}\text { Corresponding } \\
\text { weight }\end{array}$ & $\begin{array}{c}\text { Name of evaluation } \\
\text { factor }\end{array}$ & $\begin{array}{c}\text { Corresponding } \\
\text { weight }\end{array}$ \\
\hline $\begin{array}{c}\text { Financial human } \\
\text { resource }\end{array}$ & 0.15 & $\begin{array}{c}\text { Financial control } \\
\text { ability }\end{array}$ & 0.13 \\
\hline $\begin{array}{c}\text { Information } \\
\text { processing ability }\end{array}$ & 0.13 & $\begin{array}{c}\text { Financial alarm } \\
\text { ability }\end{array}$ & 0.12 \\
\hline Asset size & 0.09 & Investment ability & 0.04 \\
\hline $\begin{array}{c}\text { Financial relation } \\
\text { ability }\end{array}$ & 0.10 & $\begin{array}{c}\text { Capital utilization } \\
\text { efficiency }\end{array}$ & 0.07 \\
\hline $\begin{array}{c}\text { Financial } \\
\text { organization and } \\
\text { harmony ability }\end{array}$ & 0.14 & Distribution ability & 0.03 \\
\hline
\end{tabular}


Table 4. Comprehensive evaluation results of the financial core competitiveness

\begin{tabular}{|c|c|c|c|c|c|c|c|}
\hline Ranking & $\begin{array}{l}\text { Stock } \\
\text { code }\end{array}$ & $\begin{array}{l}\text { Stock } \\
\text { name }\end{array}$ & $\begin{array}{c}\text { Comprehensive } \\
\text { evaluation } \\
\text { value }\end{array}$ & Ranking & $\begin{array}{l}\text { Stock } \\
\text { code }\end{array}$ & $\begin{array}{l}\text { Stock } \\
\text { name }\end{array}$ & $\begin{array}{c}\text { Comprehensive } \\
\text { evaluation } \\
\text { value }\end{array}$ \\
\hline 1 & 000959 & $\begin{array}{l}\text { Beijing } \\
\text { Shougang }\end{array}$ & 5.2811 & 9 & 000778 & $\begin{array}{l}\text { Xinxing } \\
\text { Ductile } \\
\text { Iron Pipes }\end{array}$ & 3.5785 \\
\hline 2 & 000898 & $\begin{array}{l}\text { Angang } \\
\text { New } \\
\text { Steel }\end{array}$ & 4.6482 & 10 & 000708 & $\begin{array}{c}\text { Daye } \\
\text { Special } \\
\text { Steel }\end{array}$ & 3.4325 \\
\hline 3 & 000932 & $\begin{array}{c}\text { Valin } \\
\text { Steel } \\
\text { Tube \& } \\
\text { Wire }\end{array}$ & 4.5827 & 11 & 000890 & Fasten & 3.4033 \\
\hline 4 & 000825 & $\begin{array}{c}\text { Taiyuan } \\
\text { Steel }\end{array}$ & 4.5406 & 12 & 000761 & $\begin{array}{l}\text { Benxi } \\
\text { Steel }\end{array}$ & 3.2730 \\
\hline 5 & 000717 & $\begin{array}{c}\text { SGIS } \\
\text { Songshan }\end{array}$ & 4.5198 & 13 & 000961 & $\begin{array}{c}\text { Dalian } \\
\text { Jinniu }\end{array}$ & 2.8626 \\
\hline 6 & 001696 & $\begin{array}{l}\text { Zongshen } \\
\text { Industrial } \\
\text { Group }\end{array}$ & 4.4635 & 14 & 000569 & $\begin{array}{c}\text { Great } \\
\text { Wall Tech }\end{array}$ & 2.7271 \\
\hline 7 & 000709 & $\begin{array}{c}\text { Tangshan } \\
\text { steel }\end{array}$ & 4.3096 & 15 & 000656 & $\begin{array}{c}\text { ST } \\
\text { Dongyuan }\end{array}$ & 2.4216 \\
\hline 8 & 000629 & $\begin{array}{c}\text { New } \\
\text { Steel \& } \\
\text { Vanadium }\end{array}$ & 4.0934 & & & & \\
\hline
\end{tabular}

